\title{
PROFIL KEKUATAN KARAKTER DAN KEBAJIKAN PADA MAHASISWA BERPRESTASI
}

\author{
Irfan Fahmi dan Zulmi Ramdani \\ UIN Sunan Gunung Djati Bandung, Jl. A.H. Nasution 105 \\ e-mail: irfan.fahmi@yahoo.co.id
}

\begin{abstract}
Basically each person has different character strength in achieving the goal expected. The character strength becomes a typical structure of an individual's personality that distinguishes itself from the others. Individuals with high achievement motivation will attempt to set a specific goal, using some strategic measurements, highly will-power, and always worked hard. This study aimed to explore the character strength of students who are excellence in academic. The method used mix method which are combine both quantitative and qualitative approaches. The numbers of subjects in this study were 30 students from 9 faculties in UIN Sunan Gunung Djati whom selected based on the highest GPA score. The character strength had seen from the individually measurements results of the Values in Action-Inventory strenghts (VIA-IS) which consists of 240 items in the form of scale Likert. Interviews with subjects than have been conducted to gained more information related to the character strength of them. The results has showed that a strength of character typical of the outstanding students, namely Hope, Perseverance, and Spirituality.
\end{abstract}

Keywords : college students, achievement, strength character

\begin{abstract}
Abstrak
Pada dasarnya setiap individu memiliki kekuatan karakter yang berbeda dalam meraih prestasi yang diharapkan. Kekuatan karakter tersebut akan menjadi struktur khas kepribadian individu yang membedakan dirinya dengan yang lain. Individu dengan motivasi berprestasi tinggi akan berusaha untuk menetapkan tujuannya secara spesifik, menggunakan langkah-langkah yang strategis, berkemauan yang tinggi, dan dan senantiasa bekerja keras. Penelitian ini bertujuan untuk mengeksplorasi kekuatan karakter yang dimiliki para mahasiswa yang berprestasi dalam akademik. Pendekatan yang digunakan dalam penelitian ini berupa metode campuran antara pendekatan kuantitatif dan kualitatif. Jumlah subjek dalam penelitian ini berjumlah 30 orang dari 9 Fakultas UIN Sunan Gunung Djati yang dipilih berdasarkan nilai IPK tertinggi.Kekuatan karakter dilihat dari hasil pengukuran The Values in Action-Inventory Strenghts (VIA-IS) terdiri dari 240 item dalam bentuk skala Likert. Setelah itu dilakukan interview terhadap subjek untuk mengenali lebih mendalam terkait dengan kekuatan karakternya. Hasil pengukurandan wawancara menunjukan adanya kekuatan karakter khas pada mahasiswa berprestasi, yaitu Harapan, Ketekunan, dan Spiritualitas.
\end{abstract}

Kata Kunci : Mahasiswa, Prestasi, Kekuatan Karakter.

\section{PENDAHULUAN}

Pendidikan merupakan konsep penting dalam kehidupan manusia. Pendidikan menjadi satu bagian yang tidak terpisahkan dalam membentuk kepribadian inividu sebagai mahluk yang aktif dan dinamis. Menurut Undang-Undang Nomor 20 Tahun 2003 tentang Sistem Pendidikan Nasional Bab I Pasal 1 (1) pendidikan adalah usaha sadar dan terencana untuk mewujudkan suasana belajar dan proses pembelajaran agar peserta didik secara aktif mengembangkan potensi dirinya, masyarakat, bangsa dan Negara (Syah, 2010). Berbeda dengan jenjang dasar, pada jenjang perguruan tinggi sangat diharapkan munculnya generasi yang cerdas; mampu menjawab persoalan dan tantangan zaman. Oleh karenanya diperlukan keseimbangan yang nyata antara kecerdasan akademik dan kekuatan karakter.

Karakter tidak terlepas dari kepribadian manusia sendiri. Sebagaimana yang dikatakan oleh Allport mengenai kepribadian individu sebagai "Organisasi 
dinamis dalam suatu sistem psikofisis yang ikut menetukan dirinya dan lingkunganya secara khas"(Jeist \& Feist, 2010), memberikan makna bahwa setiap individu memiliki kemampuan yang berbeda dalam menghadapi situasi yang sama. Hal ini tidak terlepas dari karakter masing-masing yang memang sejak awal bervariasi.

Kekuatan karakter menjadi isu utama dalam penelitian psikologi positif. Dalam ranah psikologi positif, hal yang diutamakan adalah bagaimana menjadikan individu dengan segala potensinya menjadi lebih baik dan dikembangkan seoptimal mungkin. Mahasiswa yang berprestasi tentunya adalah individu dengan motivasi berprestasi tinggi; ia akan berusaha untuk menetapkan tujuannya secara spesifik, menggunakan langkah-langkah yang strategis, berkemauan yang tinggi, dan dan senantiasa bekerja keras dalam mencapai target dan tujuan yang ditetapkannya. Selain usaha-usaha secara nyata tentunya ada persfektif kepribadian yang dimiliki individu, sehingga membuat dirinya mendapat mampu mencapai prestasi yang baik. Terkait dengan hal itu, peneliti mencoba untuk memberikan gambaran yang spesifik mengenai kekuatan karakter yang mendasari mahasiswa berprestasi secara akademik.

\section{Kajian Pustaka}

Peterson dan Seligman (2004) memfokuskan pada kekuatan karakter (character strengths) dan kebajikan (virtues). Mereka mengartikan kebajikan sebagai ciri inti yang dihargai oleh para filsuf dan kaum religius. Kebajikan bersifat universal dan penting bagi keberlangsungan hidup. Kebajikan digolongkan menjadi enam kategori, yaitu kearifan dan pengetahuan (wisdom and knowledge), keteguhan hati (courage), perikemanusiaan dan cinta kasih (humanity and love), keadilan (justice), kesederhanaan (temperance), dan transendensi (transcendence).

Kekuatan karakter adalah unsur psikologis yang membentuk kebajikan
(Peterson \& Seligman, 2004). Dengan kata lain, setiap kebajikan terbentuk dari beberapa kekuatan karakter, misalnya kebajikan "kearifan dan pengetahuan" terdiri dari kekuatan karakter kreativitas, keingintahuan, keterbukaan pikiran, kecintaan akan belajar, dan perspektif. Apabila seorang individu mempunyai satu atau dua kekuatan karakter dari setiap kebajikan, maka individu tersebut dapat disebut mempunyai karakter yang baik.

Seligman (2002) juga memperkenalkan istilah "kekuatan khas (signature strengths)", yang merupakan karakteristik khas seorang individu. Menurut Seligman, individu dapat mencapai keberhasilan dan kepuasan emosional yang terdalam dengan meng-gunakan dan mengembangkan kekuatan khas dalam kehidupan sehari-hari, daripada berusaha amat keras untuk memperbaiki kelemahan. Kekuatan khas dapat dikatakan sebagai kekuatan yang disadari dan sering ditampilkan dalam kehidupan sehari-hari. bahwa terdapat 6 jenis kebajikan yang terdiri dari 24 kekuatan karakter. Berikut ini akan dijelaskan lebih mendalam mengenai ke24 kekuatan karakter tersebut (Peterson \& Seligman, 2004).

\section{A. Kearifan dan Pengetahuan (Wisdom and Knowledge)}

Kebajikan ini merupakan kebajikan yang berkaitan dengan fungsi kognitif, yaitu mengenai bagaimana individu memperoleh dan menggunakan pengetahuan. Kebajikan ini meliputi lima kekuatan karakter, yaitu:

\section{Kreativitas (Creativity)}

Kreativitas mengarahkan individu untuk mencapai tujuannya dengan caranya sendiri yang baru, unik, dan orisinil. Bagaimanapun, ide atau perilaku tersebut harus adaptif, yaitu harus dapat memberikan kontribusi yang positif bagi diri sendiri dan orang lain.

\section{Keingintahuan (Curiosity)}

Keingintahuan berkaitan dengan rasa ingin tahu seseorang yang mengarah 
pada munculnya keterbuka-an pada hal-hal baru, pengalaman-pengalaman yang bervariasi dan menantang. Individu yang memiliki keingintahuan akan secara aktif mencari informasi dan merasa puas bila berhasil memperoleh jawaban atas berbagai pertanyaan, dapat mempelajari sesuatu yang baru, dan mendapat pengalaman baru.

3. Keterbukaan Pikiran (Openmindedness)

Individu dengan kekuatan karakter ini akan berpikir secara menyeluruh dan memandang suatu hal dari berbagai sisi atau mempertimbangkan berbagai bukti yang ada. Individu akan secara aktif mengumpulkan informasi untuk melakukan penilaian secara objektif, sehingga tidak terjadi bias dan mampu meyakini sesuatu setelah mendapat informasi yang objektif.

\section{Kecintaan belajar (Love of learning)}

Kekuatan karakter ini mengarahkan individu untuk selalu ingin mempelajari hal-hal baru untuk mengembangkan keterampilan atau memperkaya pengetahuan yang telah dimilikinya. Individu menganggap belajar sebagai suatu tantangan.

\section{Perspektif (Perspective)}

Perspektif memungkinkan individu untuk memandang dunia secara holistik, sehingga ia dapat memahami dirinya dan orang lain. Ia mampu menyadari keterbatasan atau kelemahan dan kekuatan dirinya. Dalam mengambil keputusan, individu akan mempertimbangkan baik perasaannya maupun rasionalitasnya.

\section{B. Keteguhan Hati (Courage)}

Keteguhan hati merupakan kebajikan yang melibatkan dorongan yang kuat untuk mencapai suatu tujuan. Keteguhan hati terdiri dariempat kekuatan karakter, yaitu:

\section{Keberanian (Bravery)}

Dengan adanya keberanian, individu tidak akan mundur meskipun ia menerima ancaman, tantangan, kesulitan ataupun rasa sakit dalam mencapai tujuannya. Ia juga mampu bertahan dari tekanan kelompok (peer preasure) untuk menerima pandangan moral tertentu yang tidak sesuai dengan pandangannya sendiri.

\section{Ketekunan (Persistence)}

Individu dengan kekuatan karakter ini akan selalu menyelesaikan segala sesuatu yang telah dimulainya, meskipun menghadapi berbagai tantangan. Ia akan mengambil tantangan untuk mengerjakan proyek atau tugas yang sulit dan menyelesaikannya sesuai dengan yang telah direncanakannya.

\section{Integritas (Integrity)}

Kekuatan karakter ini mengacu pada kejujuran dan kemampuan untuk menampilkan diri apa adanya (genuine), tanpa kepura-puraan.

\section{Vitalitas (Vitality)}

Vitalitas mengacu pada gairah dan antusiasme dalam menjalani segala aktivitas. Individu dengan kekuatan karakter ini tampil sebagai pribadi yang enerjik, gembira, penuh semangat,dan aktif. Individu yang memiliki vitalitas cenderung lebih mudah menghadapi ketegangan psikologis, konflik, dan stressor.

\section{Perikemanusiaan dan Cinta Kasih (Humanity and Love)}

Perikemanusiaan dan cinta melibatkan hubungan interpersonal yang baik dengan orang lain, yang mencakup mempedulikan dan memperhatikan orang lain. Kebajikan ini meliputi tiga kekuatan karakter, yaitu:

\section{Cinta (Love)}

Cinta melibatkan hubungan dengan orang lain, saling berbagi dan memperhatikan, serta mencoba untuk dekat dengan orang lain. Individu dengan kekuatan karakter ini memandang pentingnya hubungan 
yang dekat dan intim dengan orang lain.

\section{Kebaikan Hati (Kindness)}

Kekuatan karakter ini mengacu pada keinginan yang kuat untuk bersikap baik dan memberikan bantuan kepada orang lain secara sukarela.

\section{Kecerdasan Sosial (Social intel- ligence)}

Kecerdasan sosial adalah pengetahuan yang berkaitan dengan diri sendiri dan orang lain. Dalam hal ini, individu mampu menyadari motivasi dan perasaan orang lain serta mampu memberi respons yang baik dan tepat pada orang lain. Selain itu, ia juga memiliki kesadaran akan perasaannya sendiri, mampu mengolah informasi yang bersifat emosional dengan baik, dan mampu menggunakannya untuk menuntun perilaku.

\section{Keadilan (Justice)}

Keadilan berkaitan dengan interaksi antara beberapa individu yang ada dalam kelompok dengan kelompok itu sendiri. Keadilan melandasi kehidupan yang sehat dalam suatu masyarakat. Dalam kebajikan ini, terdapat tiga kekuatan karakter, yaitu:

\section{Keanggotaan dalam kelompok (Citizenship)}

Kekuatan karakter ini mengacu pada kemampuan individu untuk bekerja keras sebagai anggota suatu kelompok, setia pada kelompok, dan melaksanakan kewajiban sebagai anggota kelompok.

2. Keadilan dan Persamaan (Fairness) Individu dengan kekuatan karakter ini akan memperlakukan orang lain secara sama, tidak membeda-bedakan. Ia memberi setiap orang kesempatan yang sama untuk berusaha dan menerapkan sanksi yang sama pula sesuai dengan kesalahan masingmasing.

\section{Kepemimpinan (Leadership)}

Ia dapat mengorganisasikan aktivitas dalam kelompok dan memastikan bahwa segala sesuatu berjalan dengan baik. Selain itu, ia juga dapat menjadi sumber inspirasi bagi anggota dalam kelompoknya, yang pada akhirnya dapat mendorong anggota kelompok untuk melakukan apa yang seharusnya mereka lakukan dan menciptakan hubungan interpersonal serta moral yang baik pula.

\section{E. Kesederhanaan (Temperance)}

Kebajikan ini mengarahkan individu untuk berpikir sebelum bertindak, untuk menghindari akibat buruk yang mungkin terjadi di kemudian hari karena tindakannya tersebut. Terdapat empat kekuatan karakter dalam kebajikan ini, yakni:

\section{Memaafkan (Forgiveness and mercy)}

Individu dengan kekuatan karakter ini mampu memaafkan orang lain yang melakukan kesalahan atau bersikap buruk kepadanya. Ia dapat melupakan pengalaman buruk di masa lalunya, tanpa paksaan dari orang lain.

2. Kerendahan Hati (Humility and modesty)

Dalam hal ini, individu tidak menyombongkan keberhasilannya. Kerendahan hati juga membuat seseorang mampu melihat kekurangan dan ketidaksempurnaan yang ada pada dirinya. Modesty lebih bersifat eksternal, yang artinya bersifat sederhana secara perilaku maupun penampilan. Sedangkan humility bersifat internal, yaitu kecenderungan individu yang merasa bahwa dirinya bukanlah pusat dari dunia.

\section{Kebijaksanaan (Prudence)}

Kekuatan karakter ini merupakan suatu bentuk manajemen diri yang membantu individu meraih tujuan jangka panjangnya. Individu akan berpikir dan memiliki perhatian penuh pada masa depan, serta menetapkan tujuan jangka panjang dan membuat perencanaan yang matang.

\section{Regulasi Diri (Self regulation)}

Individu yang memiliki kekuatan karakter ini mampu menahan diri, 


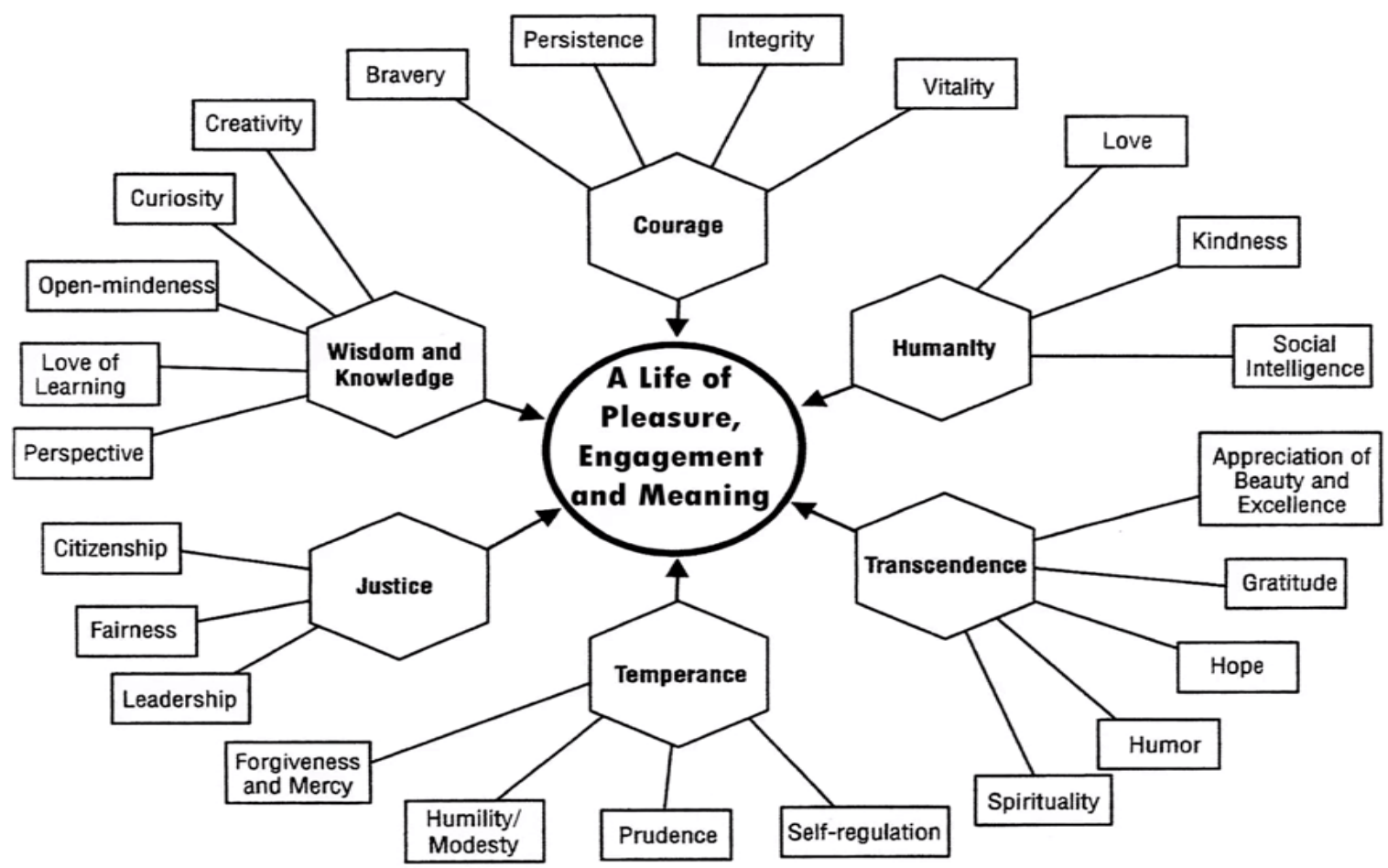

osi, nafsu, serta dorongan-dorongan lain dalam dirinya. Ia dapat mengatur apa yang dirasakan dan akan dilakukannya agar sesuai dengan situasi dan pandangan moral masyarakat.

\section{F. Transendensi (Transcendence)}

Kebajikan ini berkaitan dengan hubungan antara individu dan alam semesta, serta bagaimana individu memberi makna pada kehidupan. Kebajikan ini meliputi lima kekuatan karakter, yaitu:

1. Apresiasi terhadap Keindahan dan Kesempurnaan (Ap-preciation of beauty and excellence)

Kekuatan karakter ini membuat individu mampu menyadari dan memberikan apresiasi atas keindahan dan ke-sempurnaan.

\section{Bersyukur (Gratitude)}

Bersyukur adalah rasa terima kasih sebagai respons terhadap suatu pemberian. Individu dengan kekuatan karakter ini dapat menyadari dan bersyukur atas segala hal yang telah terjadi dalam hidupnya, serta selalu menyempatkan waktu untuk mengucapkan rasa syukur.

\section{Harapan (Hope)}

Kekuatan karakter ini berkaitan dengan bagaimana individu memandang masa depannya. Individu berpikir mengenai masa depan, mengharapkan hasil yang terbaik di masa yang akan datang, dan merasa percaya diri terhadap hasil dan tujuan.

\section{Humor (Humor)}

Dengan kekuatan karakter ini, individu dapat membawa keceriaan dan senyuman pada orang-orang di sekitarnya. Secara keseluruhan, humor dapat diartikan sebagai pikiran yang menyenangkan, pandangan yang membahagiakan yang memungkinkan individu untuk melihat sisi positif dari suatu hal.

\section{Spiritualitas (Spirituality)}

Spiritualitas membuat individu memiliki kepercayaan tentang adanya 
sesuatu yang lebih besar dari alam semesta ini. Hal ini sering digambarkan sebagai Tuhan. Individu mampu menempatkan dirinya menjadi bagian dari alam semesta. Ia menyadari makna hidupnya dan mengetahui apa yang harus dilakukannya untuk mencapaihal tersebut.

Apabila dirangkum, ke-6 kebajikan dan ke-24 kekuatan karakter tersebut dapat dilihat pada gambar 1 .

\section{METODOLOGI PENELITIAN}

Subjek pada penelitian ini adalah mahasiswa aktif yang berprestasi, berjumlah 30 orang yang merupakan mahasiswa dengan IPK tertinggi. Subjek diambil secara acak dari tiap Fakultas yang ada di di UIN Sunan Gunung Djati Bandung. Subjek diperoleh berdasarkan data yang diberikan dari bagian akademik tiap fakultas beserta data yang diambil dari keputusan Rektor UIN Sunan Gunung Djati Bandung tentang mahasiswa penerima Bidik Misi.

Alat pengumpulan data yang digunakan adalah The Values in Action-Inventory of Strenghts (VIA-IS). VIA-IS menggunakan model Likert dengan lima skala untuk mengukur derajat individu berespon terhadap pernyataan yang merefleksikan 24 karakter pada klasifikasi. Skor didapat dari rata-rata respon pada setiap skala. Character strengths yang melekat pada individu adalah lima strengths dengan skor rata-rata terbesar dari 24 daftar strengths. Peterson \& Seligman (dalam Carr, 2004 \& Seligman, 2002) menyebutnya dengan signature strengths yaitu strengths yang melekat pada diri individu. Nilai reliabilitas untuk alat ukur VIA-IS adalah 0,976 .

Dalam pelaksanaanya, individu diminta mengerjakan alat ukur VIA-IS dengan waktu sekitar 30 menit untuk pengisian 240 item dan dilanjutkan dengan wawancara terkait kekuatan karakter yang dimiliki subjek. Pertanyaan tunggal yang diajukan adalah "Kemampuan atau kekuatan apa yang dimiliki oleh subyek untuk memperoleh prestasi yang diinginkan"?

\section{DISKUSI DAN PEMBAHASAN}

Gambaran umum subyek dan hasil perhitungan dari kekuatan karakter dapat dilihat dari tabel di bawah ini :

Tabel 1. Jenis Kelamin

\begin{tabular}{|c|c|c|}
\hline $\begin{array}{c}\text { Jenis } \\
\text { Kelamin }\end{array}$ & Frekuensi & Persentase \\
\hline Laki-laki & 13 & $43,3 \%$ \\
\hline Perempuan & 17 & $56,7 \%$ \\
\hline
\end{tabular}

Tabel 2. Asal Fakultas

\begin{tabular}{lcc}
\hline \multicolumn{1}{c}{ Fakultas } & Frekuensi & Persentase \\
\hline $\begin{array}{l}\text { Psikologi dan } \\
\text { Sains dan } \\
\text { Teknologi }\end{array}$ & 6 & $20 \%$ \\
$\begin{array}{l}\text { Adab dan } \\
\text { Humaniora }\end{array}$ & 4 & $13,3 \%$ \\
$\begin{array}{l}\text { Dakwah dan } \\
\text { Komunikasi }\end{array}$ & 1 & $3,3 \%$ \\
$\begin{array}{l}\text { Ushuludin } \\
\text { FISIP }\end{array}$ & 1 & $3,3 \%$ \\
$\begin{array}{l}\text { Tarbiyah dan } \\
\text { Keguruan } \\
\text { Syariah dan } \\
\text { Hukum }\end{array}$ & 2 & $6,6 \%$ \\
\hline
\end{tabular}

Tabel 3. Profil Kekuatan Karakter dan Signature Strength

\begin{tabular}{|c|c|c|}
\hline No & Kekuatan Karakter & Nilai \\
\hline 1 & Harapan & 4.25 \\
\hline 2 & Bersyukur & 4.245 \\
\hline 3 & Spritualitas & 4.24 \\
\hline 4 & Ketekunan & 4.043 \\
\hline 5 & Keadilan dan Persamaan & 4.003 \\
\hline 6 & Cinta & 3.987 \\
\hline 7 & $\begin{array}{l}\text { Apresiasi terhadap Keindahan } \\
\text { dan Kesempurnaan }\end{array}$ & 3.957 \\
\hline 8 & Kebaikan Hati & 3.95 \\
\hline 9 & $\begin{array}{l}\text { Keanggotaan } \\
\text { Kelompok }\end{array}$ & 3.923 \\
\hline 10 & Integritas & 3.9 \\
\hline
\end{tabular}




\begin{tabular}{lll}
\hline $\mathbf{1 1}$ & Kepemimpinan & 3.857 \\
$\mathbf{1 2}$ & Vitalitas & 3.845 \\
$\mathbf{1 3}$ & Memaafkan & 3.837 \\
$\mathbf{1 4}$ & Keterbukaan Pikiran & 3.83 \\
$\mathbf{1 5}$ & Keingintahuan & 3.807 \\
$\mathbf{1 6}$ & Keberanian & 3.767 \\
$\mathbf{1 7}$ & Kecintaan Belajar & 3.757 \\
$\mathbf{1 8}$ & Kebijaksanaan & 3.75 \\
$\mathbf{1 9}$ & Kecerdasan Sosial & 3.7 \\
$\mathbf{2 0}$ & Persfektif & 3.697 \\
$\mathbf{2 1}$ & Kreativitas & 3.673 \\
$\mathbf{2 2}$ & Humor & 3.645 \\
$\mathbf{2 3}$ & Kerendahan Hati & 3.35 \\
$\mathbf{2 4}$ & Regulasi Diri & 3.323 \\
\hline
\end{tabular}

Tabel 4. Hasil Wawancara Kekuatan Karakter dan Signature Strength

\begin{tabular}{cl}
\hline Subjek & \multicolumn{1}{c}{ Respon } \\
\hline $\mathbf{1}$ & Kalau karakteristik yang aku \\
& punya tuh berani, berani apa yah, \\
& berani beda sama orang lain. \\
& Terus aku tipikal orang yang gak \\
& pernah bisa nyerah, kalau \\
& misalkan aku tuh punya target, \\
& punya tujuan yah aku harus \\
& dapatkan tujuan itu, tapi tetep aja \\
& dengan usaha yang baik. Dan \\
& kata orang sih aku, manusia full \\
& bateri gitu, jadi kaya gak da \\
& capenya da memang yang aku \\
& rasain kaya gitu, aku merasa \\
& kalau misalkan aku bisa \\
& ngelakuin itu dengan maksimal \\
& kenapa gak, jadi yah itu mungkin \\
& potensi besar yang aku punya \\
\hline $\mathbf{2}$ & Saya adalah seorang pekerja \\
& keras, saya tidak pernah mau \\
& berhenti mengerjakan sesuatu \\
& yang belum saya selesaikan. \\
\hline 3 & Saya adalah karakter orang yang \\
& bisa dibilang cukup serius, jika \\
& saya menghadapi suatu masalah \\
& dan saya akan berusaha untuk \\
mencari jawaban dari sebuah \\
masalah tersebut. Dan karakter \\
saya, jika saya akan mencapai \\
cita-cita saya dengan baik, \\
dengan berusaha sekuat tenaga
\end{tabular}

saya dan menunjukan kepada orang-orang yang ada di sekeliling saya, terutama kepada orang tua saya bahwa saya itu bisa dan mampu untuk mencapai cita-cita tersebut. Saya tipe orang yang dapat berusaha dengan baik.

\begin{tabular}{llr}
\multicolumn{4}{c}{ dengan baik. } \\
\hline $\mathbf{4}$ & Saya punya energi, saya punya \\
& tekad, saya punya tenaga, dan \\
& saya punya keyakinan untuk \\
& mencapai apa yang saya \\
& inginkan.
\end{tabular}
pragmatis, dan saya tidak mau apa yang saya lakukan itu, mengecewakan orang yang mencintai saya, saya hanya ingin melihat mereka tersenyum, ingin melihat keringat mereka saya balas dengan kesuksesan saya.

Saya adalah tipikal orang yang percaya dengan kemampuan saya, sehingga apapun yang akan saya lakukan saya selalu melihat itu dengan sangat teliti, dan saya yakin apa yang saya lakukan akan berhasil. Dalam hidup saya, saya selalu menargetkan sesuatu untuk saya capai, jadi ketika saya menginginkan sesuatu saya targetkan. Apa target saya. Sehingga saya mempunyai tujuan yang jelas, keputusankeputusan apa saja kah yang saya ambil,

7 Mungkin yang saya miliki untuk meraih prestasi itu, mungkin yang saya membedakan dengan yang lainnya, rajin ngerjain tugas, kemudian yaitu berdoa, itu mungkin yang saya miliki.

$8 \quad$ Saya adalah orang yang pekerja keras, terutama dalam tugastugas harus on time dan apabila telat, saya sangat merasa sedih, dan kemudian tidak pernah bolos kuliah, bolos itu pernah tapi lebih banyak kuliahnya. Minimal dalam satu mata kuliah itu satu 


\begin{tabular}{|c|c|}
\hline & $\begin{array}{l}\text { atau dua tidak lebih. Kemudian } \\
\text { saya sangat aktif di kelas, baik } \\
\text { itu dalam diskusi atau dalam hal- } \\
\text { hal lainnya. }\end{array}$ \\
\hline 9 & $\begin{array}{l}\text { Karakteristik yang saya miliki } \\
\text { atau sifat yang saya miliki } \\
\text { hingga saya bisa mencapai target } \\
\text { IPK tertinggi itu karena saya } \\
\text { merasa bahwa diri saya } \\
\text { membutuhkan nilai itu, bukan } \\
\text { karena sekedar saingan atau } \\
\text { ambisi. Tapi, kebutuhan yang } \\
\text { kita perlukan, karena kita } \\
\text { membutuhkan nilai itu untuk } \\
\text { mencapai cita-cita misalkan, } \\
\text { seperti saya yang planning nya } \\
\text { ke depan dan bagaimana untuk } \\
\text { keluarga, maka saya bekerja } \\
\text { semaksimal mungkin, apapun } \\
\text { yang akan saya lakukan, } \\
\text { terutama belajar tentunya dalam } \\
\text { hal yang halal gitu. Kemudian, } \\
\text { saya punya prinsip dalam diri } \\
\text { saya, bahwa dalam diri saya itu } \\
\text { harus saya kerjakan semaksimal } \\
\text { mungkin, tanpa kompromi } \\
\text { apapun. Jadi kalau saya sudah } \\
\text { punya target, apapun keadaan } \\
\text { saya seperti apapun saya akan } \\
\text { tetap berusaha sampai } \\
\text { tercapainya yang saya inginkan } \\
\text { itu. Terus, intinya jangan pernah } \\
\text { patah semangat, pantang } \\
\text { menyerah, kalau jenuh kalau } \\
\text { cape itu wajar, kalau kaya gitu } \\
\text { ya kita relaks atau santai, } \\
\text { lakukan supaya kita } \\
\text { terbangkitkan lagi untuk belajar. }\end{array}$ \\
\hline 10 & $\begin{array}{l}\text { Saya sendiri memiliki kerja } \\
\text { keras, artinya ketika berbicara } \\
\text { tugas, salah satunya tugas dari } \\
\text { dosen, kita kerjakan, dan tanpa } \\
\text { mementingkan kepentingan lain } \\
\text { selain itu. Artinya di sini ada } \\
\text { skala prioritas. }\end{array}$ \\
\hline 11 & $\begin{array}{l}\text { Saya memiliki bakat, } \\
\text { kemampuan serta motivasi yang } \\
\text { tinggi, sehingga dengan hal itu } \\
\text { bisa mengejar hal-hal yang saya } \\
\text { inginkan. Ketika saya ingin IPK }\end{array}$ \\
\hline
\end{tabular}

\begin{tabular}{|c|c|}
\hline & $\begin{array}{l}\text { tinggi, maka berusaha untuk } \\
\text { belajar serius, dan serius. Dan } \\
\text { jangan sampai apa yang kita } \\
\text { inginkan itu tidak tercapai. Tetap } \\
\text { harus pada awal tujuan saya. }\end{array}$ \\
\hline 12 & $\begin{array}{l}\text { Kerja keras, kemauan, } \\
\text { kemampuan untuk mempelajari } \\
\text { hal baru. }\end{array}$ \\
\hline 13 & $\begin{array}{l}\text { Untuk mencapai prestasi terbaik, } \\
\text { saya belajar dengan istiqomah, } \\
\text { saya belajar dengan sungguh- } \\
\text { sungguh, udah itu ikhtiar, jangan } \\
\text { lupa minta doa orang tua. Itu } \\
\text { intinya. Jadi, ketika mau UAS } \\
\text { atau belajar, jadi seringlah } \\
\text { berkomunkasi dengan orang tua. } \\
\text { Ketika kita udah berikhtiar } \\
\text { semaksimal mungkin kita harus } \\
\text { meminta doa orang tua, karena } \\
\text { doa orang tua itu bisa membantu } \\
\text { kesulitan kita, dan ketika UAS } \\
\text { itu, targetnya nilai mengisinya } \\
\text { dengan tenang, santai, jangan } \\
\text { terlalu buru-buru, dan niatkan } \\
\text { belajar itu untuk kehidupan yang } \\
\text { akan datang. }\end{array}$ \\
\hline 14 & $\begin{array}{l}\text { Saya kalau pengen UAS itu } \\
\text { harus santai, saya orangnya } \\
\text { cenderung kurang hafalan, jadi } \\
\text { untuk pelajaran yang hafalan itu } \\
\text { harus ada catatan kecil saja } \\
\text { untuk dibaca. }\end{array}$ \\
\hline 15 & $\begin{array}{l}\text { Saya adalah orang yang ambisi, } \\
\text { saya termasuk orang yang } \\
\text { belajar itu tahan berjam-jam, } \\
\text { mungkin itu kebiasaan dari SD, } \\
\text { karena saya setiap ulangan terus } \\
\text { dapat nilai di atas rata-rata, } \\
\text { karena juga saya mempunyai } \\
\text { cita-cita untuk menjadi seorang } \\
\text { dokter, oleh karena di mulai dari } \\
\text { sekarang saya harus rajin dan } \\
\text { disiplin. }\end{array}$ \\
\hline 16 & $\begin{array}{l}\text { Karakteristik yang saya miliki, } \\
\text { saya adalah penghapal cepat, } \\
\text { bisa berkonsentrasi juga, } \\
\text { walaupun waktunya sebentar } \\
\text { tapi ketika saya baca, bisa } \\
\text { menyimpan dan mudah } \\
\text { memahami materi yang }\end{array}$ \\
\hline
\end{tabular}




\begin{tabular}{|c|c|}
\hline & paikan. \\
\hline 17 & $\begin{array}{l}\text { Saya adalah orang yang ingin } \\
\text { tahu, karena hal-hal yang baru } \\
\text { itu sebagai acuan untuk lebih } \\
\text { mengetahui. Saya dapat IPK } \\
\text { sangat tinggi karena saya adalah } \\
\text { tipe penurut sejak semester satu } \\
\text { sampai empat. Saya adalah } \\
\text { orang yang tegas akan keinginan } \\
\text { saya. }\end{array}$ \\
\hline 18 & $\begin{array}{l}\text { Intinya belajar dengan fokus apa } \\
\text { yang harus kita pelajari. } \\
\text { Ditambah dengan kemampuan } \\
\text { kita untuk memahami materi } \\
\text { kuliah di jurusan tersebut. } \\
\text { Misalnya saya harus mampu } \\
\text { mempelajari bahasa Inggris dan } \\
\text { bahasa Arab lebih giat lagi. }\end{array}$ \\
\hline 19 & $\begin{array}{l}\text { Saya mempunyai motivasi yang } \\
\text { tinggi dan juga tujuan yang jelas, } \\
\text { kalau dalam organisasi namanya } \\
\text { master plan, jadi plan-nya itu } \\
\text { jelas, targetnya jelas, tujuannya } \\
\text { jelas, karena motivasi dalam diri } \\
\text { saya karena ingin, pokoknya } \\
\text { sayang kalau misalkan kuliah itu } \\
\text { hanya mengukir prestasi doang. } \\
\text { Intinya saya punya karakteristik } \\
\text { motivasi dan tujuan yang jelas. }\end{array}$ \\
\hline 20 & $\begin{array}{l}\text { Karena saya punya keinginan, } \\
\text { punya motivasi yang kuat dan } \\
\text { keinginan untuk mencapai yang } \\
\text { terbaik, tetapi tidak terlepas dari } \\
\text { namanya manusia biasa saya ada } \\
\text { jenuhnya, saya ada bosannya, } \\
\text { tapi karena dari awal saya punya } \\
\text { tanggungjawab bahwa saya } \\
\text { memilih ini, sehingga saya akan } \\
\text { bertanggungjawab dan konse- } \\
\text { kuen dengan apa yang saya pilih. } \\
\text { Kemudian, saya bukan tipe } \\
\text { perfeksionis, mungkin orang } \\
\text { mengerjakan sesuatu itu yang } \\
\text { terbaik, saya lebih baik jadi diri } \\
\text { saya sendiri saja. Saya tidak } \\
\text { perlu sempurna mengikuti } \\
\text { prosedur yang ada, tapi yang } \\
\text { penting inilah yang saya lakukan } \\
\text { dengan cara saya. }\end{array}$ \\
\hline 21 & Saya punya kompetesi di kelas, \\
\hline
\end{tabular}

\begin{tabular}{|c|c|}
\hline & $\begin{array}{l}\text { berhubung saya berorganisasi } \\
\text { juga, jadi saya membuktikan } \\
\text { bahwa orang yang ikut } \\
\text { organisasi itu bisa melebihi } \\
\text { orang-orang yang hanya duduk } \\
\text { di akademi saja. Adapun, ada } \\
\text { niat dan keseriusan untuk } \\
\text { belajar, ada hal-hal yang ingin } \\
\text { dicapai seperti saya ingin } \\
\text { menunjukan bahwa saya mampu. }\end{array}$ \\
\hline 22 & $\begin{array}{l}\text { Pertama ada semangat dari orang } \\
\text { tua, doa, terus banyak membaca } \\
\text { dan banyak mengulang pelajaran } \\
\text { yang telah disampaikan oleh } \\
\text { dosen. Banyak didukung oleh } \\
\text { fasilitas dari buku dan teknologi. }\end{array}$ \\
\hline 23 & $\begin{array}{l}\text { Sebenarnya pada dasarnya untuk } \\
\text { meraih kesuksesan seperti } \\
\text { prestasi, bukan hanya dari segi } \\
\text { intelektualnya, tapi dari segi } \\
\text { kerja kerasnya, karena itu adalah } \\
\text { awal dari berprestasi. Kebetulan } \\
\text { di kimia itu ada banyak } \\
\text { penelitian gitu, nah mungkin } \\
\text { karena kerja keras kita membagi } \\
\text { waktu antara membaca buku, } \\
\text { dan sebagainya. Dengan kuliah } \\
\text { yang kita jalani. }\end{array}$ \\
\hline 24 & $\begin{array}{l}\text { Untuk mencapai prestasi yang } \\
\text { diinginkan, pertama saya punya } \\
\text { tujuan, yaitu tujuan akhir apa } \\
\text { yang harus saya capai, ketika } \\
\text { saya punya tujuan akhirnya } \\
\text { berarti saya harus mencapai } \\
\text { langkah-langkah atau step-step } \\
\text { yang telah dipersiapkan se- } \\
\text { belumnya, jadi dengan semangat } \\
\text { dan perjuangan yang keras, saya } \\
\text { akan berusaha untuk mewujud- } \\
\text { kan apa yang harus saya } \\
\text { harapkan dan saya cita-citakan. } \\
\text { Adalah bagaimana cara kita } \\
\text { mengatur waktu kita, sehingga } \\
\text { segala sesuatu baik di kuliah } \\
\text { atau organisasi, kita bisa } \\
\text { mengatur seefisien mungkin, } \\
\text { sehingga semuanya bisa saling } \\
\text { melengkapi, sehingga bisa } \\
\text { mencapai apa yang kita } \\
\text { inginkan. }\end{array}$ \\
\hline
\end{tabular}


25 Jadi, intinya itu ada semangat dalam diri sendiri, punya semangat tinggi, punya impian dan keinginan dan punya targetan dulu. Misalnya kita pengen IP tinggi, otomatis kalau misalkan kita pengen itu, maka harus belajar ekstra keras dan tentunya sangat tinggi dalam semangat, ada juga doa dan ada juga tuntutat dari beasiswa juga, dan ada dukungan dari orang tua. Kalau saya sendiri saya selalu percaya diri dengan apa yang saya harapkan, dan semangat saya itu jarang galau. Saya berusaha untuk ceria dan gak pernah mikirin orang, itu udah hidup mereka.

\begin{tabular}{|c|c|}
\hline 26 & 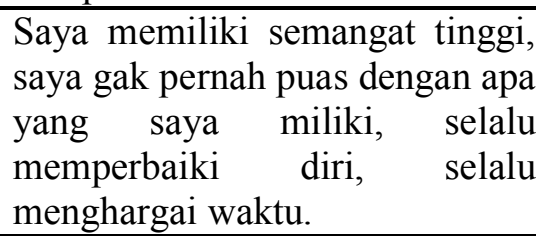 \\
\hline 27 & $\begin{array}{l}\text { Saya tuh rajin, niat saya untuk } \\
\text { bisa sukses, saya bisa } \\
\text { membanggakan orang tua dan } \\
\text { salah satunya bisa meraih } \\
\text { prestasi tinggi. }\end{array}$ \\
\hline 28 & $\begin{array}{l}\text { Pertama jujur, gigih, konsisten } \\
\text { dan fokus. Saya harus } \\
\text { berkembang setiap hari, kalau } \\
\text { misalkan kita stagnasi dalam } \\
\text { pertumbuhan, itu menjadi } \\
\text { motivasi untuk mengembangkan } \\
\text { bakat dan kemampuan. Dan } \\
\text { hasilnya itu lumayan memuas- } \\
\text { kan. }\end{array}$ \\
\hline 29 & $\begin{array}{l}\text { Karena saya punya kemampuan } \\
\text { dalam akademik, karena saya } \\
\text { suka baca dan saya punya bisa } \\
\text { interaksi, jadi saya bisa } \\
\text { melakukannya. }\end{array}$ \\
\hline 30 & $\begin{array}{l}\text { Saya punya antusiasme yang } \\
\text { tinggi, saya meyakini bahwa } \\
\text { hidup itu sebab akibat, jadi kalau } \\
\text { kita ingin sukses, maka kita } \\
\text { harus mencapai itu. Kemudian, } \\
\text { saya tidak pernah berhenti untuk } \\
\text { belajar, terutama dalam bidang }\end{array}$ \\
\hline
\end{tabular}

saya menulis dan jurnalisme.

\section{PEMBAHASAN}

Berdasarkan pengolahan data terhadap jawaban responden pada skala VIAIS diperoleh 5 kekuatan karakter dengan nilai tertinggi, diantaranya Harapan 4,25, Bersyukur 4,245, Spritualitas 4,24, Ketekunan 4,043 dan Keadilan dan Persamaan 4,003. Sehingga dapat disimpulkan bahwa kekuatan karakter yang paling menonjol pada subyek penelitian berkaitan dengan prestasi adalah kekuatan karakter Harapan. Sebagaimana dengan makna harapan itu sendiri menyatakan bahwa individu dalam penelitian ini memiliki pandangan yang sangat tinggi terhadap masa depannya, semua dibentuk dan diciptakan untuk masa depannya.

Apabila dibandingkan dengan hasil wawancara terhadap subjek mengenai aspek-aspek kekuatan karakter menunjukan bahwa mayoritas subyek memiliki keyakinan yang sangat tinggi terhadap masa depannya. Setiap subjek memiliki target dan tujuan yang jelas serta terukur dalam menjalani kehidupan dan rencana di masa depan. Untuk mencapai target tersebut skala prioritas dan perencanaan yang sistematis dibuat sedemikian rupa. Setiap tahapan dijalani dengan kerja keras, tekad kuat, motivasi yang tinggi dan konsistensi sehingga tidak ada kata menyerah untuk mencapai target prestasi yang diharapkan. Setiap hal dievaluasi untuk memastikan ada perbaikan diri dan perkembangan signifikan dalam diri mereka. Di sisi lain usaha keras tersebut dibarengi dengan doa sebagai wujud penyempurna usaha tersebut. Hal penting lainnya adalah keyakinan akan kemampuan diri bahwa mereka punya potensi dan kemampuan untuk bisa mencapai apa yang mereka targetkan dan harapkan di masa depan. Peneliti berasumsi bahwa data yang diperoleh dalam hasil wawancara menambah validasi hasil pengukuran yang dilakukan sebelumnya. 


\section{SIMPULAN}

Penelitian ini memberikan informasi bahwa kekuatan karakter yang secara khas dan paling menonjol pada individu mahasiswa berprestasi adalah Harapan, Ketekunan dan Spiritualitas.

Jumlah subjek yang terbatas 30 orang seharusnya bisa ditingkatkan jumlahnya. Selain juga prosedur pengambilan sampel yang harus diperbaiki sehingga bisa memperoleh sampel yang kurang representatif. Selain itu, pemilihan tema yang diajukan terlalu umum dan data wawancara yang masih terbatas.

\section{DAFTAR PUSTAKA}

Anastasi, Anne dan Susana Urbina, (2007). Tes Psikologi Terjemahan edisi ketujuh. Jakarta. PT Indeks.

Atkinson, Rita dkk, (2010). Pengantar Psikologi jilid 1.Tanggerang. Interaksara.

Creswell, John W, (2010). Research Design. Yogyakarta. PustakaPelajar.

Friedenberg, Lisa, (1995). Psychological Testing (Design, Analysis, and Use). United States 0f America. Allyn and Baccon Companny.

Hadi, Sutrisna, (2001). Metodologi Research. Yogyakarta. ANDI.

Peterson, Christopher dan Seligman, Martin, (2004). Character Strengths and Virtues A Handbook and Classification. New York. Oxford University Press.

Ratri, Iddha Diyaning, (2008). Profil Kekuatan Karakter dan Kebajikan (Character Strengths and Virtues) pada Psikolog. Tugas Akhir. Universitas Indonesia. Tidak diterbitkan.
Seniati, Lichie dkk, (2011). Psikologi Ekperimen. Jakarta. PT. Indeks.

Schlosberg, dan Woodworth, (1938). Experimental Psychology Revised. New Delhi. Gulab-Primlani, Oxford $\&$ IBH Publishing.

Sobur, Alex, (2003). Psikologi Umum. Bandung. Pustaka Setia.

Sudjana, (2005). Metoda Statistika. Bandung. Tarsito.

Siegel, Sidney, (1992). Statistik Non Parametrik Terjemahan. Jakarta. Gramedia.

Syah, Muhhibin, (2010). Psikologi Pendidikan. Bandung. Remaja Rosdakarya.

Tashakkori, Abbas dan Charles, (2010). Mix Methodology. Yogyakarta. PustakaPelajar.

http://thelia27.wordpress.com/tag/persepsikedalaman/ pada 28 Februari 2014 pukul 12.30 .

http://www.google.com/url?sa=t\&rct=j\&q $=\&$ esrc $=$ s\& $\&$ source $=$ web $\& \mathrm{~cd}=3 \& \mathrm{cad}$ $=$ rja\&sqi $=2 \& v e d=0 \mathrm{CDoQFjAC} \&$ url $=\mathrm{http} \% 3 \mathrm{~A} \% 2 \mathrm{~F} \% 2 \mathrm{Fbk} 2009$.files. wor dpress.com\%2F 2012\%2F04\%2Fmak alah.docx\&ei=ySdWUvDDPIGMrQ eE_YGYCg\&usg=AFQjCNEkO03T 9sD7K-

JNP68oT5mfl3bPZA\&bvm=bv.5389 9372,d.bmk pada Kamis, 10 Maret 2014 pukul 11.11 WIB.

http://sententias.org/2013/10/07/universalvirtues/ pada Sabtu, 7 Juni 2014 pukul 12.38 WIB. 